Szabó Miklós, Vinnai Edina (szerk.)

\title{
A törvény szavai
}

\author{
(Miskolc, Bíbor Kiadó, 2018. 313 pp. ISBN 978-615-5536-61-8)
}

\author{
Kovács Tímea \\ E-mail:kovacs.timea@kre.hu
}

A jog és a nyelv területén lassan húsz éve vizsgálódó nyelvészekből és jogászokból álló interdiszciplináris kutatócsoport 2014-ben indította a jog mint társadalmi intézményrendszer müködésének nyelvi feltételrendszerére irányuló kutatását. A 2014 és 2018 között folytatott munkát, az OTKA K-112172 számú projekt keretében elnyert $A$ tisztességes eljárás nyelvi aspektusai: A jogi nyelv hatása a joghoz való hozzáférés érvényesülésére címü pályázat támogatta. A kutatás e szakaszában a kutatócsoport tagjai, jogászok és nyelvészek, azt vizsgálták, hogy vajon vannake a magyar jogi nyelvnek olyan sajátosságai, melyek a közérthetőségét akadályozzák. A kutatás fenti szakaszát a 2018. május 25 -én megtartott $A$ jogi nyelv érthetősége és a joghoz való hozzáférés címü konferencia zárta. A konferencia anyagából született meg $A$ törvény szavai címü kötet, amelyben 13 tanulmány kapott helyet.

A tanulmányok fő vizsgálódási területét tekintve két fö részre oszthatók. Az első hat tanulmány a jogi nyelv érthetőségét és az esetlegesen akadályozó tényezőket vizsgálja négy fő nyelvi szempontból: az állítmányi szerkezetek, alanyi szerkezetek, mellérendelés és alárendelés és a központozás. A második hét tanulmány a jog érthetőségét inkább a jogi praxis, vagyis a mélyebb logikai struktúrák, a történetiség, a bírói gyakorlat, valamint a jogtudomány, a pragmatika, a szemantika és szemiotika közös elméleti keretében való értelmezés szemszögéből kutatja.

Vincze Veronika, az MTA-SZTE Mesterséges Intelligencia Kutatócsoport és Szegedi Tudományegyetem tudományos munkatársa, A miskolci jogi korpusz nyelvi jellemzöi, címü bevezetö tanulmányában, részletesen bemutatja a fenti kutatás alapját szolgáló Miskolci Jogi Korpuszt (MJK). A miskolci korpusz az első magyar jogi nyelvre szövegeket tartalmazó nagyméretü korpusz összesen 2,4 millió szövegszót és 150 ezer mondatot tartalmaz (Vincze 2018: 10). A korpusz összeállítása során a kutatók arra törekedtek, hogy a magyar jogi nyelvhasználat lehető legszélesebb spektrumát fedjék le. Ennek megfelelően a korpuszt további - összesen 6 - körülbelül azonos terjedelmü ( 25 ezer mondatot tartalmazó) részkorpusz al-

Hivatkozás: Kovács T. 2020. Szabó M., Vinnai E. (szerk.) A törvény szavai. Fordítástudomány 22. évf. 1. szám. 118-124. DOI: https://doi.org/10.35924/fordtud.22.1.10 
kotja (kivételt képez a bírósági átiratokat tartalmazó, 18 ezer mondatból álló korpusz, mely folyamatosan bővül). Fontos kiemelni a korpusz sokszínüségét. A Kódexjog részkorpusz öt magyar törvény teljes szövegét tartalmazza; az Egyéb Jogszabályok, a fenti öt törvényen felüli törvényekből és egyéb jogszabályokból véletlenszerüen kiválasztott szövegekből áll; az Ítéletek részkorpuszban kaptak helyet bírósági ítéletekből véletlenszerüen kiválasztott dokumentumok; A Magyarázó jellegü szövegek részkorpuszba egyes jogszabályok miniszteri indoklásai, másrészt jogi egyetemeken használt tankönyvek szövegei kerültek; a Jogi Fórumok részkorpuszba a kutatók laikusok jogi természetü kérdéseire vonatkozó szövegek válogattak; az Átiratok részkorpuszt pedig bírósági tárgyalásokon és rendőrségi kihallgatáson rögzített hangfelvételek átirata képezi.

A korpusz megalkotásánál a kutatók tehát külön figyelmet fordítottak arra, hogy a jogi nyelv közérthetőségének vizsgálata a jogi nyelv különféle típusaira kiterjedjen. A kutatás során a fentiekben leírt korpusz a jogi nyelvre vonatkozó mintákkal szolgált, melyeket a köznyelvben előforduló mintákkal hasonlítottak össze. A köznyelvi referencia korpusznak a Szeged Treebank-et választották, mely 82000 mondatot és 1,5 millió szövegszót tartalmaz. A két korpuszt morfológiai és szintaktikai elemzéssel hasonlították össze. Megvizsgálták a szövegekben elöforduló szófajok gyakoriságát, szintaktikai függőségi, szemantikai és lexikai elemzést is folytattak. A korpuszokat alkotó szövegeket az érthetőség szempontjából is öszszehasonlították. A kutatást végzők a statisztikai alapon nyert eredményeket kvalitatív módszerekkel is elemezték és arra a következtetésre jutottak, hogy a fenti szempontok alapján a ,párbeszéd jellegü szövegek állnak legközelebb a köznyelvhez érthetöségi szempontból, míg a legnehezebben érthetőknek a metajogi (magyarázó) szövegek bizonyultak" (Vincze 2018: 36).

Dobos Csilla, a Miskoci Egyetem Bölcsészettudományi Kar docense Állítmányi szerkezetek a magyar jogi nyelvben címü tanulmányában a magyar jogi nyelv állítmánnyal kapcsolatos szintaktikai jellemzőit mutatja be. A szerző az állítmányi szerkezeteket a miskolci jogi korpuszban az alábbiak szerint vizsgálja: igei állítmányok, az állítmányok szerkezeti felépítése, a névszói állítmányok, az igei állítmányok helye a mondatban. Az igei állítmányok kvantitatív és kvalitatív jellegü vizsgálatát követően Dobos Csilla megállapítja, hogy ,,[...] az MJK-ban [...] a korpusz összes szóelőfordulásának 9\%-át alkotó igék többsége jelen időben (64\%), kijelentő módban (93\%), egyes számban (87\%), illetve egyes szám harmadik személyen (94\%) fordul elö" (Dobos 2018: 52). Az állítmányok szerkezeti felépítését illetően a szerző megállapítja, hogy a vizsgált korpuszra a kettős állítmánytól eltekintve egyszerü, összetett és halmozott állítmányok egyaránt jellemzőek. Az egyszerü igei állítmányi szerkezetek ,több mondatszintü bővítményt (alany, tárgy, határozó) és emellett több szerkezetszintü tagot (pl. tárgy, határozó, jelző)" tartalmaznak (Dobos 2018: 53). A korpuszra jellemző az analitikus szerkesztésü, összetett igealakokból álló egyszerü igei állítmány is. A névszói állítmányok kapcsán a szerző megállapítja, hogy az összetett állítmányok többségében a melléknevek, melléknévi igeneves szerkezetek ( $\mathrm{pl}$. -andó / -endö), illetve modális jelentésü pasz- 
szív melléknévi igenevek (pl. -ható / -hető) alkotják a névszói részt. Az igei állítmányok helyét abból a szempontból vizsgálja a szerző, hogy vajon az ige helye a mondatban mennyiben befolyásolja az adott mondat érthetőségét. Az MJK-ban - a Fórum részkorpusz kivételével - az ige közelebb áll a mondat végéhez, mint az elejéhez, a tárgyi bővítmény pedig gyakran nem csak az igét és az alanyt előzi meg, hanem a mondat legelején szerepel. Fentiek alapján megállapítható tehát, hogy a vizsgált korpuszra jellemző mondatszerkesztés ,,nem támogatja az olvasó koherencia igényét, itt a pragmatikai megközelítés segít" (Dobos 2018: 68).

Balogh Dorka, a Pázmány Péter Katolikus Egyetem, Jog- és Államtudományi Kar szaknyelvoktatója, jogi és gazdasági szakfordító, Alanyi szerkezetek a magyar jogi nyelvben címü tanulmánya alapvetően az MJK-ban, de más jogi szaknyelvi szövegekben is előforduló alanyi szerkezeteket elemzi. A szerző az alany meghatározása és grammatikaelméleti jellemzését követően a korpuszban, illetve a részkorpuszokban kvantitatív elemzések segítségével nyert adatokat elemez kvalitatív szempontból. Vizsgálódásainak középpontjában szintén a jogi nyelv - laikusok számára való - érthetősége és a jogi nyelvre jellemző alanyi szerkezetek közötti összefüggések állnak. A kutatás eredményeképpen megállapítja, hogy a jogi szövegek mondatszerkesztése eltér a köznyelvitöl. Az írott jogi szaknyelvben az alanyt általában bővítmények láncolata elözi meg a mondat elején, sőt az alanyt és az állítmányt is halmozott bővítmények sorozata választja el egymástól. Ez a két jelenség „közérthetőséget gátló tényező(k)” (Balogh 2018: 94). A szerző ugyanakkor rámutat a részkorpuszokban megfigyelhető eltérésekre: ,a kódexek és a jogszabályok mondatainak legelején ritkán áll alany, míg a köznyelvi szövegekben és fórumok szövegeiben az alannyal kezdődő mondatok száma jóval magasabb" (Balogh 2018: 92).

Kurtán Zsuzsa, a Miskolci OTKA Kutatócsoport tagja, Mellérendelés a magyar jogi nyelvben címü tanulmányában a magyar jogi nyelvre jellemző tipikus kötőszós és kötőszó nélküli mellérendelés szintaktikai környezetének főbb jellemzőit tárja fel és írja le az MJK adatai alapján. Tanulmányában konkrét példákon keresztül elemzi a mellérendelést, mint az írott jogi szöveg érthetőségét jellemzöen akadályozó tényezőt is. Részletesen példák segítségével szemlélteti az (és; valamint; illetve; illetőleg; majd) kötőszavas és kötőszó nélküli kapcsolatos mellérendelések, a (vagy) kötőszavas választó, a(z) (azonban; de; viszont) kötőszavas ellentétes, a kötőszavas (ezért; így; tehát) következtető, valamint a magyarázó ( $a z a z)$ utótagú mellérendeléseket. A részkorpuszok mellérendelő szerkezet használatában változatos nyelvi mintákat talál. A vizsgálat eredményei alapján az İtélet részkorpusz tartalmazza a mellérendelő kötőszavakat a legnagyobb arányban és változatosságban. Ugyanakkor a Jogi fórum részkorpusz mutatja a legnagyobb hasonlóságot a köznyelvi beszéd sajátosságaival. A Jogi fórum részkorpusz a köznyelvit is meghaladó arányban és változatos módon használja a mellérendeléseket megvalósító kötőszavakat. A szerző véleménye szerint ezek bár formailag kötőszavaknak tekinthetők, valójában diskurzusjelölők. A mellérendelés és érthetőség összefüggését illetően a szerző kiemeli, hogy a jogi nyelvhasználatban az értele- 
mezhetőséget befolyásolhatja a „mellérendelt elemek száma (például hosszú felsorolások nyílt szerkezetü mellérendeléseiben), valamint a kötőszó jelölése vagy annak hiánya" (Kurtán 2018: 121). Ugyanakkor a mellérendelés nyelvi elemei között fennálló tartalmi-logikai kapcsolatok felismerése a nyelvi rendszeren kívül eső társadalmi jelenségek, többek között a jog és egyén szaknyelvek regisztereinek keveredése, az egyszerüsítés, a jogi nyelv közérthetősége iránt növekvő igény egyaránt befolyásolják.

Sajgál Mónika, a Miskolci OTKA Kutatócsoport tagja, Alárendelés a magyar jogi nyelvben címü tanulmánya a jogi szaknyelvre jellemző alárendelö típusokat írja le, majd megvizsgálja, hogy a MJK hat részkorpuszában milyen - a köznyelvtől - eltérő alárendelő szerkezetek figyelhetők meg. A kutatás eredményei alapján megállapítja, hogy a vizsgált jogi szövegekre jellemző a többszörösen összetett, gyakran közbeékelést tartalmazó alárendelő mondatok használata. Az alárendelö szerkezetekben használt kötőszavak a részkorpuszokban érdekes rétegződést mutatnak. A legtöbb és leggyakoribb különböző alárendelő kötőszó a köznyelvi szövegekben, a fórumban és a tankönyvekben és ítéletekben a leggyakoribb. Érdekes ugyanakkor, hogy a kódexjogban és a jogszabályokban egyaránt két kötőszó - a hogy és a $h a-$ dominál. Az alárendelö mellékmondatok típusait tekintve is érdekes rétegződést mutatnak a részkorpuszok: ,a kódexjogra egyértelmüen a feltételes mellékmondat és az alanyi, tárgyi, valamint helyhatározói mondatrészt kifejező minőségjelzői vonatkozó mellékmondatok dominanciája jellemző" (Sajgál 2018: 151). Ugyanakkor a fórumokban és ítéletekben gyakran előfordul a hogy kötőszóval bevezetett függő idézés, mely a köznyelvi szövegekre jellemzö.

Kurtán Zsuzsa, a Miskolci OTKA Kutatócsoport tagja, a Központozás a magyar jogi nyelvben címü tanulmánya a jogi szövegek központozásának általános jellemzőit mutatja be. A jogi MJK és köznyelvi SZK korpuszokban előforduló írásjelek statisztikai elemzése alapján mindkettőben az írásjelek jelentős aránya mutatható ki. A jogi részkorpuszokban némileg magasabb $(16,8 \%)$, míg a köznyelvi korpuszban (15,8\%) alacsonyabb az írásjelek előfordulási aránya (159). Az egyes írásjelek gyakorisága azonban a jogi és köznyelvi korpuszban hasonló: az első helyen a vessző áll, amit második, vagy harmadik helyen követ a pont. A jogi korpuszban azonban magasabb arányban fordul elő a zárójel. Természetesen a paragrafusjel a kódexjog részkorpuszban a legmagasabb. Noha a központozás nagy mértékben hozzájárul ahhoz, hogy a gondolatokat írásban koherens módon jelöljük, a jogi nyelvre jellemző központozás bizonyos esetekben éppen az érthetőséget nehezíti. A szerző ezek közül kiemeli a nem egyforma hosszúságú részeletek alkalmazását pontokkal jelölt felsorolásokban, vagy a szövegekbe ékelt szövegrészletek használatát. Erre való tekintettel a szerző hangsúlyozza, hogy „,élszerü a felsorolások összefoglalása, a tételek csoportosítása, rövidítése" (Kurtán 2018: 179).

Markovich Réka, a Centre for Philosophy and Social Science, London School of Economics and Political Science munkatársa, A jogszabályok logikai mélystruktúrája című hetedik tanulmányban jogelméleti szempontból elemzi a jogszabá- 
lyokban használt jogi nyelv és a logikai szerkezetek egymáshoz való viszonyát. Tanulmányát két nagy részre osztja. Az első részben a propozicionális logika, a másodikban a deontikus logika és a jogszabály szövegbeli összefüggéseit tárgyalja. A propozicionális logika 16 igazságfüggvénye közül a köznyelvben leggyakrabban használt ötöt - a negációt, konjunkciót, diszjunkciót, konnegációt és kondocionálisat - mutatja be részletesen példák segítségével. Érdekes, hogy a propozicionális logikai kapcsolat azonosítását nehezítö, ezáltal a megértést is akadályozó - a hétköznapokban is használt - kifejezések között megemlíti az illetve és illetőleg szókat. E kötőszavak használata esetében nem egyértelmü, hogy konjunkciót (és), vagy diszjunkciót (kizáró vagy-ot) fejeznek ki. A deontikus logikai modalitások közül a kötelezőséget, a megengedettséget és a tilalmat részletezi. A tilalom nyelvi kifejezése kapcsán érdekes példaként hozza fel a Büntetö Törvénykönyvet (Btk.). Noha a Btk. azokat a cselekményeket sorolja fel, ,amelyek deontikus minősítését illetően aligha van kétségünk a tilalom felöl, a tilos szó vagy a fent említett megoldások (nem lehet, nem szabad, nem + hatóképző igei szószerkezet) nem szerepel a jogszabályban egyszer sem" (Markovich 2018: 196). A tilalmat a büntetendő melléknévi igenéves szerkezet fejezi ki, pl. „Aki mást megöl, büntett miatt öt évtől tizenöt évig terjedő szabadságvesztéssel büntetendő" (Markovich 2018: 197). Összegzésképpen a szerző hangsúlyozza a logikai szempontok jelentőségét az értelmezés szintjén és a jogalkotás folyamatában is, a konkrét megszövegezés kapcsán.

Gedeon Magdolna, a Miskolci Egyetem, Állam- és Jogtudományi Kar docense, A magyar jogi nyelv történetéröl címü tanulmányban a magyar nyelv történelmi szempontú fejlődését tekinti át. Leírja, hogy a 15-16. századig Magyarországon a latin nyelvü írásbeliség uralkodott. A 15. században ugyanakkor a vidéki nemesség körében kiadott okiratokban egyre több magyar nyelvü kifejezés jelenik meg. A latin azért továbbra is uralta a jogélet nyelvét. A reformáció hozta meg a 16. század második felében a magyar írásbeliség fellendülését. A szerző a magyar nemzeti nyelv kialakulásában olyan példákat említ, mint Sylvester János Grammatica Hungarolatina műve, vagy a 16. században megjelent Werbőczy Hármaskönyv. A Hármaskönyv jelentősége, hogy az európaitól eltérő magyar szokásjogot foglalta össze. Illetve ez volt az első olyan jogi munka, melyet 1565-ben Weres Balázs magyarra fordított, Magyar Decretum címen. A 17-18. században megtorpant a magyar jogi nyelv kialakulása. Az 1784. nyelvrendelet a németet írta elö a Monarchia hivatalos nyelvének. A németesítésre való törekvés azonban lendületet adott a magyar nyelvújítási törekvéseknek. A magyar jogi szaknyelv végül a 19. században szorította ki a latin nyelvet. A magyar jogi szaknyelv kialakulásában az egyik legnagyobb kihívás az egységes terminológia kidolgozása volt. A szerző erre példának hozza a latin dos, appellatio és provocatio szavak különböző magyar nyelvü megfeleltetéseit a történelem során.

Puklus Márta, szakfordító, tolmács, a Miskolci Egyetem, Bölcsészettudományi Kar egyetemi tanársegédje, Tolmácsolás a tárgyalóteremben, »Elvesztettem a fonalat, hol tartunk? « címü tanulmányában a bírósági tolmácsolást mint kommu- 
nikatív szituációt vizsgálja. Bírósági jegyzőkönyvekben a tolmácsolást is rögzítő hangfelvételek átiratát elemzi és hasonlítja össze a jegyzőkönyvezést és tolmácsolást az 'interpreting' (tolmácsolás) és 'interpretation' (értelmezés) keretében. Arra keresi a választ, hogy vajon bírósági tolmácsolási helyzetben mit várnak el a tolmácstól: tolmácsolást vagy értelmezést? A jegyzőkönyvek adatai alapján a szerző arra a következtetésre jut, hogy a bírák elvárásaival szemben, akik pusztán a lexikai, szó szerinti megfeleltetést hangsúlyozzák, a „tolmácsolásnál fontos az ekvivalencia minden szinten történő megteremtése" (Puklus 2018: 232). Összegzésképpen a szerző megállapítja, hogy nehéz meghatározni a tolmács szerepét a tolmácsolási helyzetben, mivel „sem a bíróság, sem az idegen nyelvü fél, sem a tárgyalás egyéb résztvevői nincsenek pontosan tisztában a nyelvi közvetítés összetettségével" (Puklus 2018: 239).

Ződi Zsolt, a Corvinus Egyetem docense $A$ jog érthetőségének határai. Meg tudják-e oldani a nyelvészek a jogi szövegek érthetetlenségének problémáját címü tanulmányában a jogi szövegek érthetőségének nyelvi akadályait veszi számba. Írásában azt vizsgálja, hogy a jog érthetősége, illetve az azt akadályozó nyelvi tényezők hogyan befolyásolják a joghoz való hozzáférést. Az érthetetlenség főbb példáit a nyelvi egyszerüsítési mozgalom, a Plain English Movement (PEM) mozgalom keretében megjelent dokumentumok alapján elemzi három tipikus jogi eljárási, folyamatos igazodás és laikus problémamegoldás - helyzetben. Arra a következtetésre jut, hogy a nyelvi érthetőségben a lexikai és szintaktikai szinteken túl a pragmatikai szempontok is dominálnak. Arról van ugyanis szó, hogy ,az életbeli történések nem a jogi szövegeknek megfelelöen szervezödnek ..., így megoldásuk speciális hermeneutikai erőfeszítést - applikációt - igényel" (Ződi 2018: 258). Az érthetőség szempontjából fontos figyelembe venni azt a tényt is, hogy a jogban a köznyelvben is használt szavak sajátos jogászi jelentést kapnak. A szavak jelentése tehát „,végső soron a használati, alkalmazási szokásokban gyökerezik” (Ződi 2018: 259). Fontos szempont továbbá, hogy a jogi szaknyelv más szakterületek lexikai regiszteréből is merít terminusokat, ami szintén nehezíti az érthetöséget. Összességében tehát bár fontos a nyelvészek szerepe a jogi nyelv érthetőségének elősegítésében, ,,egyedül minden érthetetlenségi problémát bizonyosan nem tudnak megoldani” (Zödi 2018: 260).

Pázmándi Kinga, a Neumann János Egyetem, Gazdaságtudományi Kar; ELTE Gazdálkodástudományi Intézet docense A jog nyelvi dimenziói és a fogyasztóvédelem »devizahiteles " perek szereplöinél azonositható nyelvi attitüdök címü tanulmányában a jog nyelvi aspektusait a fogyasztóvédelmi közjog területein vizsgálja. A devizahiteles fogyasztói kölcsönökkel kapcsolatban indított perekben vizsgálja a jogi cselekvéseket indukáló általános nyelvi mintákat. Ezt követően egy konkrét esettanulmányon keresztül mutatja be a nyelvi cselekvés dimenzióit. Vizsgálódásai eredményeképpen megállapítja, hogy a szövegek értelmezésében leginkább a jogi pragmatika kerete nyújthat segítséget. Hozzáteszi, hogy ,,a perekben, a tárgyalótermi diskurzusaikban a jogászok nyelvi cselekvéseinek valódi magyarázatát (értelmét) gyakran nem a textus, hanem a kontextus adja” (Pázmándi 2018: 280). 
Vinnai Edina, a Miskolci Egyetem Állam- és Jogtudományi Kar docense »Megértette a figyelmeztetést? « A figyelmeztetések és tájékoztatások közlése a büntetőeljárásokban címü tanulmányában a Miskolci Jogi Korpusz két beszélt nyelvi alkorpuszában azt vizsgálja, hogy a büntetőeljárásokban (rendörségi kihallgatáson, tanú (sértett) kihallgatása, terhelt kihallgatása) kritikus szerepet játszó tájékoztatásokat és figyelmeztetéseket a laikusok valóban megértik-e. Vizsgálata arra is kiterjed, hogy vajon a bírák a tárgyalások során mennyiben alkalmazzák a 2017. év folyamán az ország valamennyi bíróságán megszervezett „Közérthetőség és szakszerüség a bírósági jogalkalmazásban" kötelező képzésen javasolt gyakorlatokat. Az empirikus vizsgálat tárgyát rendörségi kihallgatásokon rögzített hangfelvételek, valamint a bírósági tárgyalásokon - a bírák engedélyével - rögzített felvételek adták. A 2016-2017. években gyüjtött hangfelvételek elemzését követöen a szerző megállapítja, hogy ,azok a bírák, akik a kutatásban részt vettek, a figyelmeztetések és tájékoztatások közlése során valóban törekednek azok világos, egyértelmü és a laikusok egyéni körülményeit figyelembe vevő megfogalmazására" (Vinnai 2018: 295). Hangsúlyozza ugyanakkor, hogy további kutatások feladata megvizsgálni, hogy a laikusok mennyire értik meg a nekik címzett tájékoztatásokat és figyelmeztetéseket.

Szabó Miklós, a Miskolci Egyetem Állam-és Jogtudományi Kar egyetemi tanára $A$ szavak ura, Pragma vs. Praxis című zárótanulmányában azt vizsgálja, hogy a jogi aktusok mennyiben értelmezhetők a szemantika és pragmatika elméleti keretében. Megállapítja, hogy a jogi normák által rögzített cselekvések beszédés pragmatikai, de jogi aktusok is, melyek ,,jogi következményeket vonnak maguk után" (Szabó 2018: 302). Ugyanakkor azt is állítja, hogy a pragmatika felől nézve jelentés nincs, csak adott helyzetek, melyek ismeretében meg lehet konstruálni a jelentést. Ha a jogot azonban normatív keretrendszernek tekintjük, akkor kérdés, hogy a benne foglalt szöveg hogyan értelmezhető. A jelentés kontextuális járulék nélkül való értelmezését a textualizmus irányzata képviseli. Ök elutasítanak minden kontextuális értelmezést, vagyis pragmatikai szemléletet és bírói aktivizmusnak definiálják a szituatív értelmezést. Ugyanakkor rámutat arra, hogy a normától eltérő - egyedi - esetekben a szöveg kontextus nélküli értelmezése nem megoldás. Ilyen esetekben szükség van a praxisra, amikor is ,,az értelemképzés a jelentés fölé kerekedhet" (Szabó 2018: 313).

A fentiekben bemutatott kötet egyedülálló vállalkozás. A kutatásban részt vevő nyelvészek és jogászok Magyarországon elsőként létrehozott hat részkorpuszból álló jogi korpuszban végzett kvantitatív és kvalitatív kutatási módszerekkel arra keresik a választ, hogy hol húzódik az érthetőség határa a jog (praxis) és a nyelvtudomány (pragma) dimenziójában. A kötet alapvető fontosságú a jogi szövegek alkotóinak és (fel)használóinak, de a jogi nyelv közvetítésében részt vevő fordítók, tolmácsok és lektorok számára is rendkívül fontos olvasmány. A kötet tanulmányai elősegítik a jogi helyzetben - eltérő nyelvi és jogi rendszerek közötti eredményes nyelvi közvetítést a jelentés és értelmezhetőség különböző rétegeinek alapos bemutatásával. 